\title{
Synthesis of Polyoxazolines Using Glycerol Carbonate Derivative and End Chains Functionalization Via Carbonate and Isocyanate Routes
}

Giardi Chloé, ${ }^{1,2}$ Lapinte Vincent, ${ }^{1} *$ Nielloud Françoise, ${ }^{2}$ Devoisselle Jean-Marie, ${ }^{2}$ Robin Jean-Jacques ${ }^{1}$

${ }^{1}$ Institut Charles Gerhardt, Montpellier, UMR 5253 CNRS-UM2-ENSCM-UM1. Equipe: Ingénierie et Architectures Macromoléculaires, Université Montpellier 2 - Bât. 17 - CC1702, Place Eugène Bataillon, 34095 Montpellier Cedex 5, France.

${ }^{2}$ Institut Charles Gerhardt, Montpellier, UMR 5253 CNRS-UM2-ENSCM-UM1. Equipe MACS, 8 rue de l'Ecole Normale, 34296 Montpellier cedex 5, France.

AUTHOR EMAIL ADDRESS: vincent.lapinte@univ-montp2.fr

\section{RECEIVED DATE}

TITLE RUNNING HEAD: Bio-based initiator for functional polyoxazoline synthesis.

CORRESPONDING AUTHOR FOOTNOTE: Institut Charles Gerhardt Montpellier UMR5253 CNRS-UM2-ENSCM-UM1 - Equipe Ingénierie et Architectures Macromoléculaires, Université Montpellier II, Place Eugène Bataillon, bâtiment 17, case courrier 17-02. 34095 Montpellier Cedex 5, France.

Tel. 33-4-67-14-48-32 Fax. 33-4-67-14-72-20

vincent.lapinte@univ-montp2.fr 


\title{
Keywords
}

Bio-based initiator, glycerol carbonate, polyoxazoline, telechelic polymer.

\begin{abstract}
We report the cationic ring-opening polymerization of 2-methyl-2-oxazoline (MOx) using bio-based initiator (GCTs). The functional initiator GCTs was prepared by tosylation of the corresponding alcohol: glycerol carbonate (GC). The termination stage of the polymerization was achieved in presence of $\mathrm{KOH}$ and the telechelic polyoxazoline carrying five-membered cyclic carbonate and oxazolium end groups $\left(\mathbf{G C}-\mathbf{P O} \mathbf{x}^{\text {ium }}\right)$ was converted to $\left((\mathbf{H O})_{2}\right.$-POx-OH $)$ carrying $\alpha$-diol and $\omega$-hydroxyl groups. End-functionalized polyoxazolines $(\mathbf{H O})_{2}$-POx-OH with $\mathrm{Mn}$ ranging from 4200 to $8400 \mathrm{~g} \cdot \mathrm{mol}^{-1}$ were synthesized. According to GPC results, the polymerizations of MOx using GCTs and other initiator coming from 1,2-isopropylideneglycerol (Solk-Ts) were compared. On the basis of FT-IR and NMR spectroscopies, the chemical modification of end chains of polyoxazolines was investigated by two alternative synthetic routes. The isocyanate route is a postpolymerization urethanization. The nucleophilic reactivity of the $\alpha$-diol and $\omega$-hydroxyl groups of $(\mathbf{H O})_{2}-\mathbf{P O x}-\mathbf{O H}$ was studied with functional isocyanate (TESPI).In the carbonate route, the electrophilic reactivity of $\alpha$ and $\omega$-end groups of GC-POx ${ }^{\text {ium }}$ were explored with amine. It was demonstrated that during the termination stage of the polymerization in presence of allylamine both urethane linker in $\alpha$-end chain was synthesized and the $\omega$-oxazolium group was converted into terminal amine. The carbonate route is an alternative to synthesize urethane without isocyanate.
\end{abstract}




\section{Introduction}

Poly(oxazoline)s have emerged recently as materials of importance in surface chemistry and in biomaterials science.[1] Polyoxazoline bearing short alkyl substituent, e.g., methyl or ethyl group, in the side 2-position are water-soluble. Among numerous water-soluble polymers, POxs are attractive for their low acute toxicity and have been approved by US Food and Drug Administration (FDA).[2,3] Functional polyoxazolines can be prepared either by the polymerization of functionalized oxazoline monomer or by the modification of telechelic POx. To prepare telechelic POx, functionalized group can be introduced at the initiation stage of the polymerization of 2-oxazolines ("initiator method") or at the termination stage by reacting the living end of the propagating polymer with a nucleophile ("terminator method"). The synthesis of telechelic POx using molecules coming from renewable sources such as vegetable oils are currently underway in our laboratory.[4] Recently, industrial applications have emerged around the use of feedstock from renewable resources because sustainability will become increasingly important for the chemical industry.[5,6] Among them, fats and oils could become one of the major players in the chemical industry in the near future. Their competitive cost, worldwide availability, and built-in functionality make them attractive for numerous commercial applications. The growing production of biodiesel by transesterification of oil with methanol or ethanol is responsible for the overproduction of glycerine. Consequently, the price of glycerine has dropped dramatically. Glycerol is an intermediate in the synthesis of a large number of compounds used in industry (Solketal@: 1,2-isopropylidene-glycerol, glycerol carbonate, glycidol, dihydroxyacetone...) (Scheme 1).[7] A bio-based key bifunctional compound is glycerol 1,2-carbonate (GC, 4hydroxymethyl-1,3-dioxolan-2-one) employed as a solvent,[8] additive, monomer,[9-10] and chemical intermediate. GC can be produced by transesterification of ethylene carbonate or 
dimethyl carbonate.[11] In our strategy, glycerol carbonate GC was converted by tosylation in glycerol carbonate tosylate (GCTs) which was employed as functional initiator in 2methyl-2-oxazoline (MOx) polymerization. The tosylation of GC has already been mentioned but the use of GCTs as initiator in polymer area has never been described to our knowledge.[12]

Herein, we report an easy route to synthesize functional polyoxazolines $\left((\mathbf{H O})_{2}-\mathbf{P O x}-\mathbf{O H}\right)$ using GCTs. Kinetic study of the polymerization was investigated and the initiation step was examined in detail. Moreover the control of molecular weights was targeted and the molecular weights were compared to those obtained with other initiator coming from Solketal ${ }^{\circledR}$ (SolkTs). Before (GC-POx $\left.{ }^{\text {ium }}\right)$ and after $\left((\mathbf{H O})_{2}\right.$-POx-OH $)$ the termination stage of the polymerization, POxs carried carbonate, oxazolium end groups and diol, hydroxyl end groups, respectively. We explored the reactivity of the end groups in urethanization reactions. Usually urethane groups are prepared from isocyanate and alcohol reaction. An alternative route was also studied with the reaction of five-membered cyclic carbonate with amine which could afford Non Isocyanate PolyUrethane (NIPU).[13-15] The strategies were examined with model reactants. The further functional polymers can result in various materials with different properties to meet different application needs. 


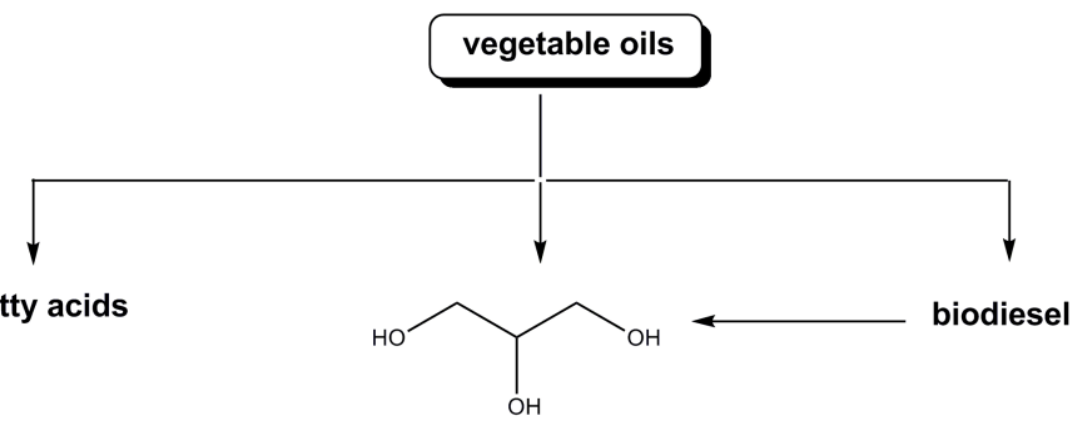

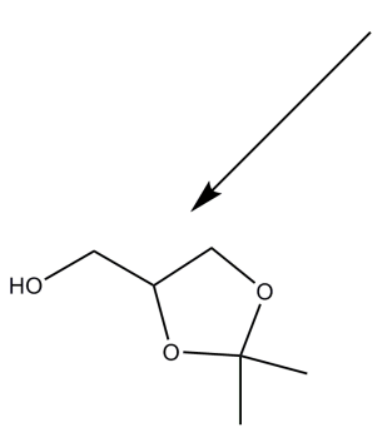

Solketal

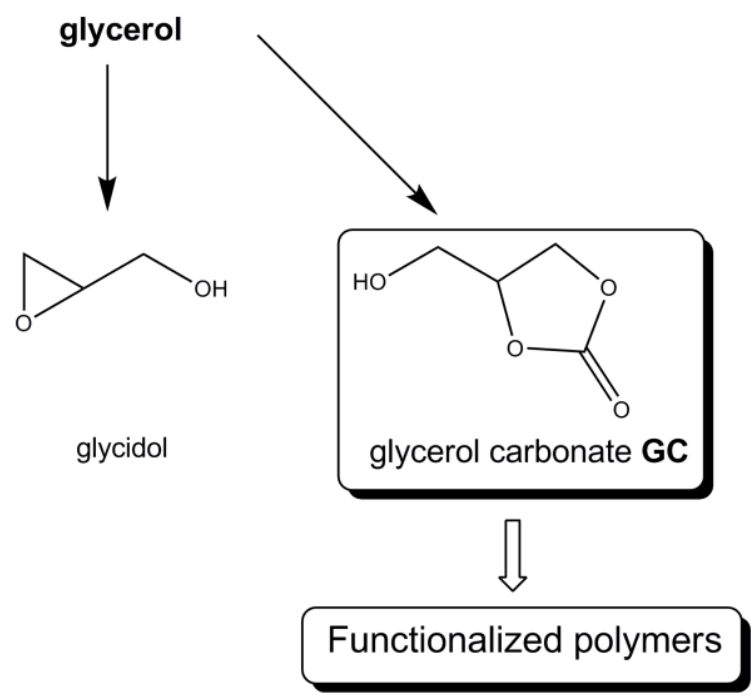

Insert Scheme 1. 


\section{Results and discussion}

\section{Synthesis of GCTs initiator}

In order to synthesize functional polyoxazolines, we combined the use of bio-based functional initiator derivated from glycerol and the chain end modification. Carbonates based on glycerol, such as glycerol carbonate GC, are gaining interest due their simple preparation, versatile properties and chemical reactivity. Functionalization of hydroxyl function of GC was already investigated with various groups.[16] Starting from GC numerous compounds as glycerol carbonate tosylate GCTs have already been described in the literature by Tatibouët et al.[17] After 6h of reaction at RT, GCTs was easily isolated using the difference of physical characteristics of GC and GCTs as illustrated in Scheme 2. GCTs appears as a very interesting reagent due to the double electrophilic reactivity of tosylate and carbonate groups.

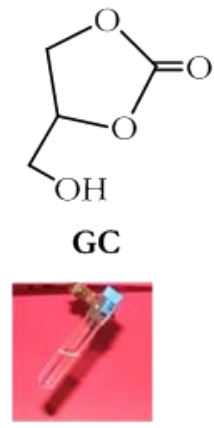

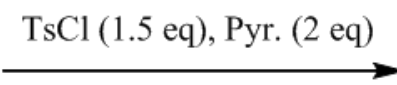

$\mathrm{CH}_{3} \mathrm{CN}, 6 \mathrm{~h}, \mathrm{R}$ T

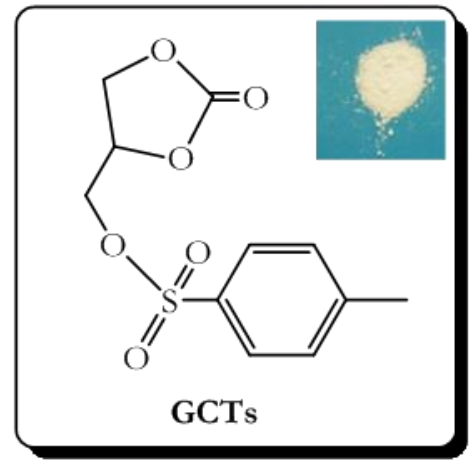

Insert Scheme 2.

\section{Synthesis of $(\mathrm{HO})_{2}-\mathrm{POx}-\mathrm{OH}$ polymer}

In our work the polymerization of MOx was investigated using GCTs as initiator of cationic ring-opening polymerization (CROP) as shown in Scheme 3. The CROP of MOx was carried out in acetonitrile at 61 or $81{ }^{\circ} \mathrm{C}$. During the termination stage the propagating species GC- 
POx ${ }^{\text {ium }}$ reacted with a $\mathrm{KOH}$-saturated methanolic solution at RT for $24 \mathrm{~h}$ and gave $(\mathbf{H O})_{2}$ POx-OH. The resulting (HO) $)_{2}-\mathbf{P O x}-\mathbf{O H}$ was purified by slow precipitation from cold diethyl ether. In presence of $\mathrm{KOH}$ the carbonate and oxazolium end groups of GC-POx ${ }^{\text {ium }}$ were converted into $\alpha$-diol and $\omega$-hydroxyl groups, respectively. The reactivity of five-membered cyclic carbonate group has been the subject of considerable research. $[18,19]$ The carbonate protective group is baso-labile and converted in situ to diol group without further step of deprotection. The complete conversion of carbonate group to diol group was checked by FTIR spectroscopy with the disappearance of the peak at $1765 \mathrm{~cm}^{-1}$ corresponding to $\mathrm{C}=\mathrm{O}$ carbonate and the appearance of the peak assignable to $\mathrm{O}-\mathrm{H}$ stretching at $3437 \mathrm{~cm}^{-1}$. In a previous study, Binder et al. described the cationic ring-opening polymerization of MOx using a derivative of GC carrying a dioxolane group: Solk-Ts (Solketal $\left.{ }^{\circledR}\right) .[20]$ The conversion of dioxolane into diol end group was realized in a supplementary step under acidic conditions. In our case, the reactivity of carbonate group led in situ polymerization and end group deprotection (Scheme 3).

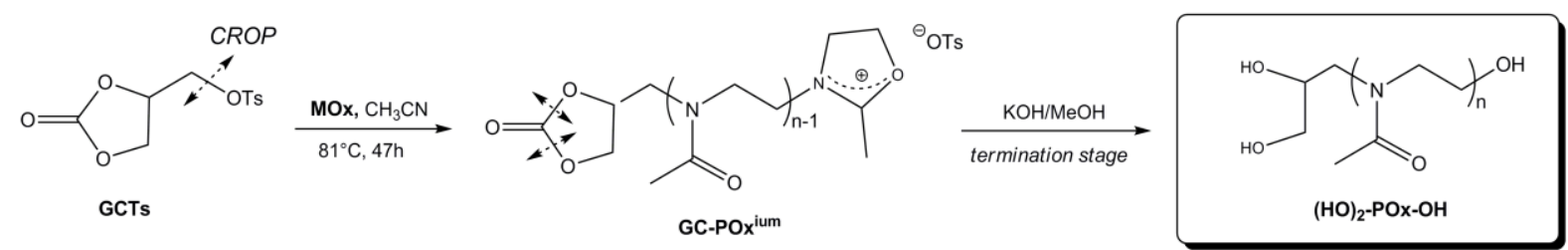

\section{Insert Scheme 3.}

The efficiency of GCTs as initiator in the MOx polymerization was investigated by ${ }^{1} \mathrm{H}$ NMR spectroscopy as illustrated in Figure 1. [GCTs $] /[\mathbf{G C T s}]_{0}$ Ratio was calculated from the integration of the signals corresponding to aromatic protons of unreacted GCTs at 7.75 and $7.35 \mathrm{ppm}$ in respect to signals corresponding to $\mathrm{TsO}^{-}$specie in the polymer end chain at 7.65 and $7.10 \mathrm{ppm}$ acting as counteranion of oxazolium propagating specie. $\mathrm{TsO}^{-}$specie appeared 
when the nitrogen of a MOx unit reacted onto GCTs initiator. The formation of $\mathrm{TsO}^{-}$was slow and revealed a slow initiation step of the CROP of MOx using GCTs. In addition some unreacted initiator remained until complete monomer consumption and the calculated efficiency ratio of GCTs was around $60 \%$.

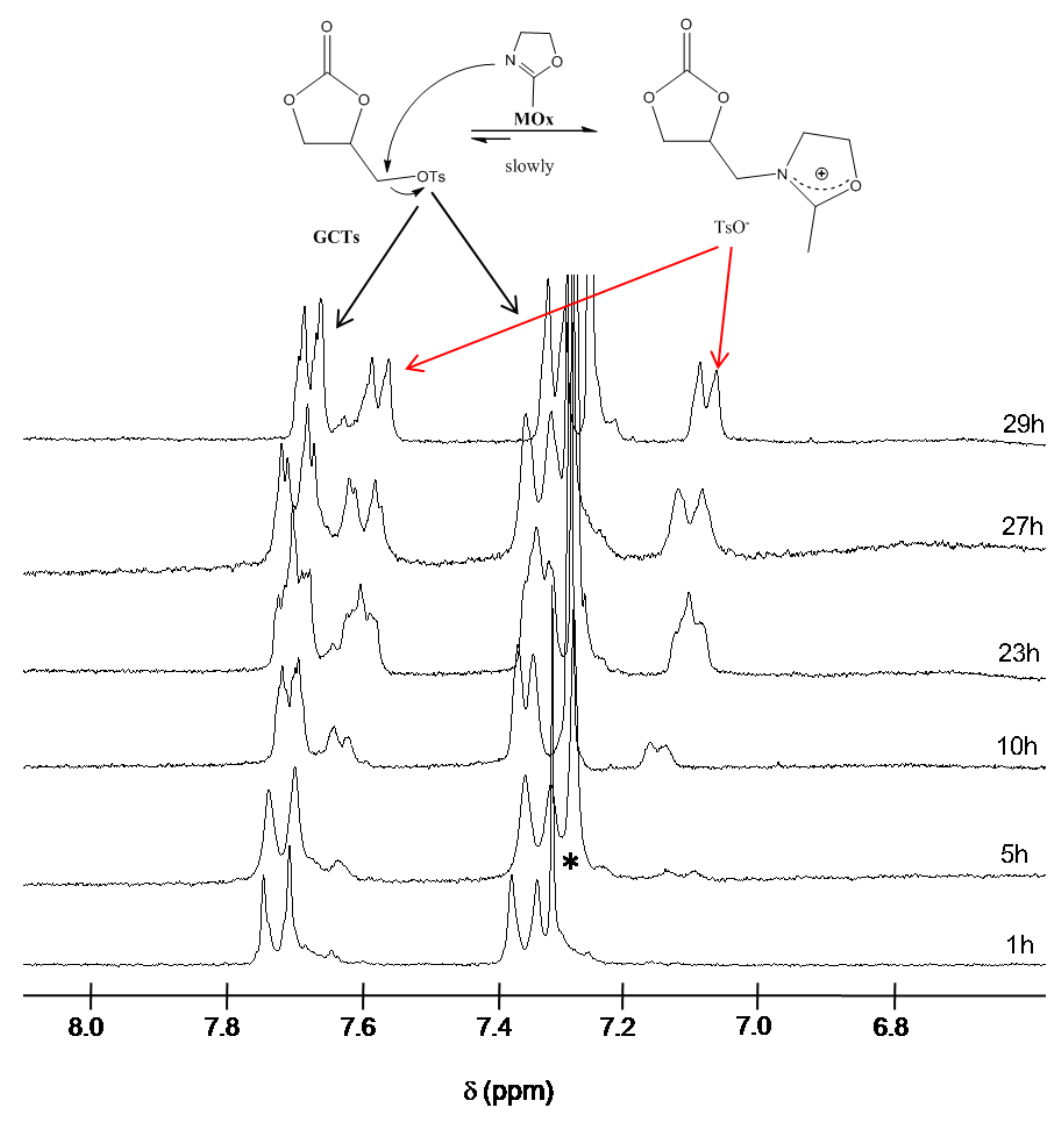

Insert Figure 1.

A preliminary kinetic study of cationic ring-opening polymerization of MOx using GCTs initiator was investigated. First MOx conversion versus time was determined for $\overline{D P_{n}^{t h}}=30$ by ${ }^{1} \mathrm{H}$ NMR experiments in $\mathrm{CD}_{3} \mathrm{CN}$ as shown in Figure 2. The $\mathrm{CH}_{2}$ protons of the monomer were observed at $\delta 4.4$ and $3.7 \mathrm{ppm}$ and shifted in a broadened peak at 3.5-3.1 ppm in the corresponding polymer. Their respective intensities were used to calculate the monomer concentration as a function of reaction time. The influence of the temperature on kinetic 
polymerization was studied at 61 and $81^{\circ} \mathrm{C}$. Whatever the temperature the conversion was higher than $96 \%$ and the final reaction time logically decreased with the temperature. The final time was more than 3 -folder at $81^{\circ} \mathrm{C}$ than $61^{\circ} \mathrm{C}$.

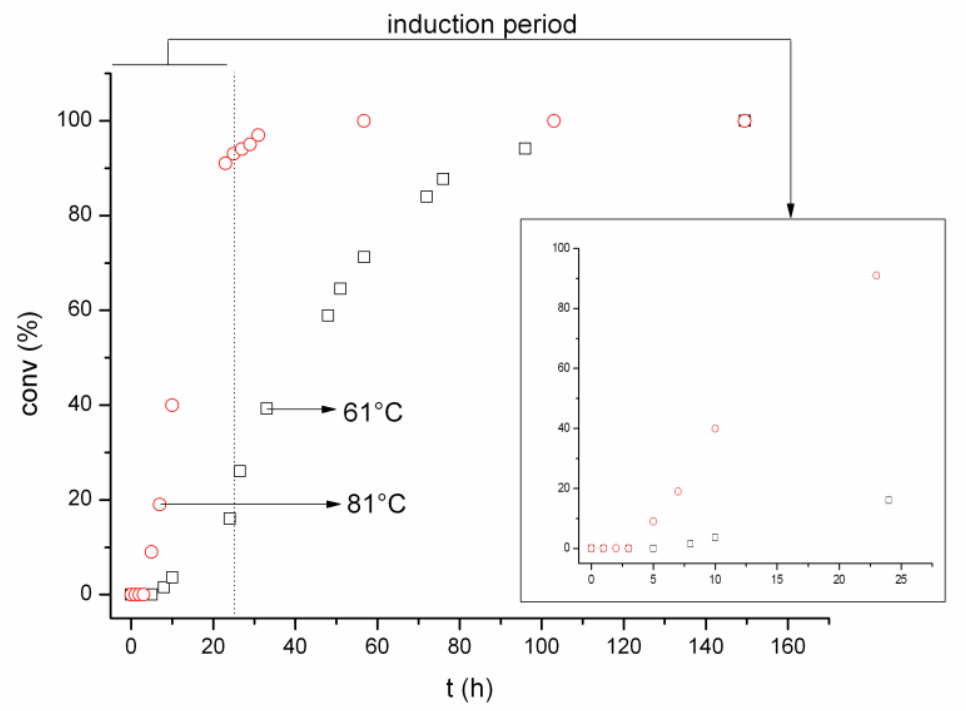

Insert Figure 2.

Whatever the temperature a latency period was observed and ranged from 4 to 8 hours at 81 and $61^{\circ} \mathrm{C}$ respectively. The latency period during the CROP of MOx was also observed using others initiators.[21] The phenomenon may be related to quite different rate constants between the first step $\left(\mathrm{k}_{\mathrm{p} 1}\right)$ (Equation 1) and subsequent propagation steps $\left(\mathrm{k}_{\mathrm{pn}}\right)$ (Equation 2) in the polymerization mechanism. The slow first propagation step could be explained by the stabilization of GCTs by interaction between carbonate and sulfonate groups of GCTs.[22] It has to be mentioned that the degradation of the cyclic carbonate did not occur at the early stage of the polymerization (checked by FTIR spectroscopy) and so could not explain the inhibition period.

$$
\mathrm{GCTs}+\mathrm{MOx} \stackrel{\mathrm{k}_{\mathrm{ps}}}{\rightarrow} \mathrm{GC}-\mathrm{POx}^{\mathrm{ium}} \quad \text { equation } 1
$$




$$
\mathrm{GC}-\mathrm{POx}^{\mathrm{ium}}+(\mathrm{n}-1) \mathrm{MOx} \stackrel{\mathrm{k}_{\mathrm{pnn}}}{\longrightarrow} \mathrm{GC}-\mathrm{POx}_{\mathrm{n}}^{\mathrm{ium}} \quad \text { equation } 2
$$

Based on ${ }^{1} \mathrm{H}$ NMR analyses, $\ln \left([\mathrm{M}]_{0} /[\mathrm{M}]\right)$ versus reaction time revealed a downward curvature at the early stage of the polymerization corresponding to a decrease of growing centers concentration (Figure 3).[23] This non linear behavior at the early stage corresponds to the effect of slow initiation step on kinetics. After this period, $\ln \left([\mathrm{M}]_{0} /[\mathrm{M}]\right)$ versus time was found to be linear indicating that the concentration of active chains remains constant throughout the polymerization i.e. no irreversible termination reaction occurred during polymerization. The linear part of $\ln \left([\mathrm{M}]_{0} /[\mathrm{M}]\right)$ versus reaction time led to the determination of the rate constant of polymerization $\left(\mathrm{k}_{\mathrm{app}}\right)$. The $\mathrm{k}_{\mathrm{app}} \mathrm{s}$ for the polymerization of MOx were calculated at 61 and $81^{\circ} \mathrm{C}$. Usual kinetic law can be written according to Equation 3:

$$
-\frac{\mathrm{d}[\mathrm{M}]}{\cdot}=\mathrm{k}_{\mathrm{mmn}} \cdot\left[\mathrm{P}^{*}\right] \cdot[\mathrm{M}] \quad \text { equation } 3
$$

Where $[\mathrm{M}]$ and $\left[\mathrm{P}^{*}\right]$ are the concentrations of the monomer and propagating species, respectively. Assuming that the concentration of propagating species is equal to the initial initiator concentration $[\mathrm{I}]_{0}$, Equation 3 can be integrated in Equation 4:

$$
\ln \frac{[\mathrm{M}]_{0}}{[\mathrm{M}]_{\mathrm{t}}}=\mathrm{k}_{\mathrm{app}} \cdot[\mathrm{I}]_{0} \cdot \mathrm{t} \quad \text { equation } 4
$$

As expected the $k_{\text {app }}$ values decreased with temperature, $3.710^{-5}$ and $1.010^{-5} \mathrm{~L}_{\mathrm{mol}} \mathrm{m}^{-1} \cdot \mathrm{s}^{-1}$ for 61 and $81^{\circ} \mathrm{C}$, respectively. The propagation rate constant for the cationic polymerization of MOx 
using GCTs initiator at $81^{\circ} \mathrm{C}$ was lower than those obtained with MeOTs and MeI initiators in dimethylacetamide, $24010^{-5}$ and $22210^{-5} \mathrm{~L} \cdot \mathrm{mol}^{-1} \cdot \mathrm{s}^{-1}$, respectively.[24]

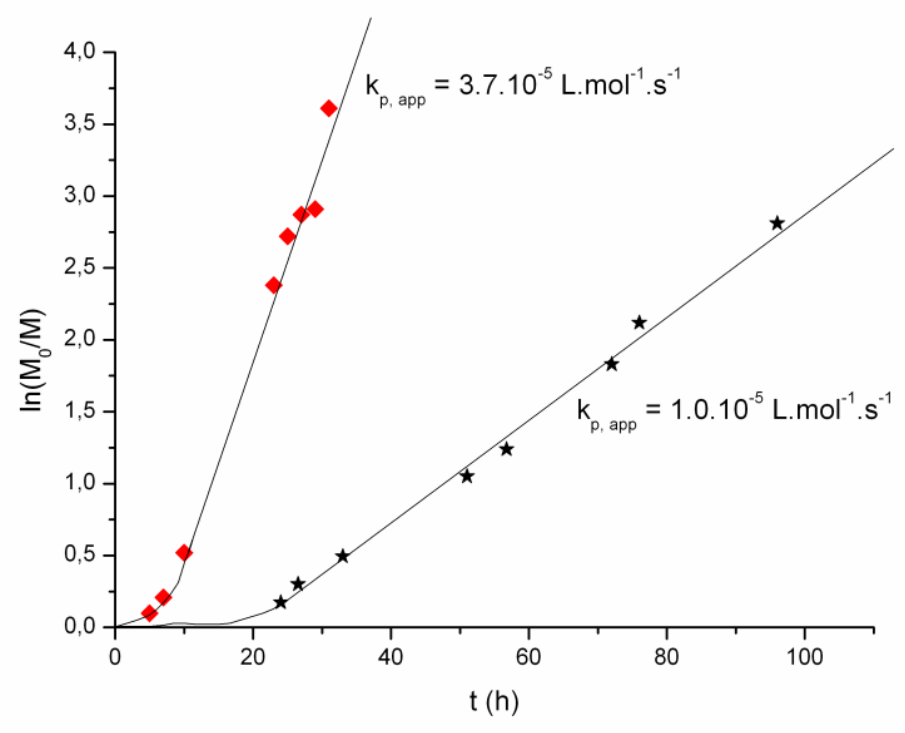

Insert Figure 3.

The cationic ring-opening polymerization of MOx initiated by GCTs was compared to the polymerization using Solketal ${ }^{\circledR}$ derivative: Solk-Ts as summarized in Table 1. The study revealed than the times of polymerization were similar. All obtained polymers were characterized by GPC to determine the molecular weights and the polydispersity indexes. The influence of the temperature on the molecular weight was studied at 61 and $81{ }^{\circ} \mathrm{C}$ (entries 1 and 2 Table 1). For both initiators the lower values of polydispersity index were reached at $61^{\circ} \mathrm{C}$ whereas a better control of molecular weights was obtained at $81^{\circ} \mathrm{C}$. Therefore a series of POx polymers were synthesized at $81^{\circ} \mathrm{C}$ with varying $[\mathrm{M}]_{0} /[]_{0}$ between 10 and 40 (entries 2-5 Table 1). The molecular weight distribution of the obtained polymer using GCTs was close to 1.4 whereas various values were observed in the case of Solk-Ts. Moreover GCTs initiator offered lower polydispersity index than Solk-Ts. In both cases, the experimental 
number-average molecular weights measured by GPC analysis were higher than expected Mn. The explanation was the low efficiency of the GCTs initiator as mentioned in Figure 1 even if the efficiency of Solk-Ts was not investigated in the previous study of Binder et al. One supplementary explanation could be the adsorption of the polymer onto the gels of the GPC columns as already mentioned in the case of polyoxazolines.[25] In addition a plateau appeared when molecular weight attained around $8400 \mathrm{~g} \cdot \mathrm{mol}^{-1}$. The plateau could be caused by chain transfer reactions and could explain shoulders which appear in the GPC traces for higher molecular weights (Figure 4).

\begin{tabular}{|c|c|c|c|c|c|c|c|c|c|c|c|c|c|}
\hline \multirow{3}{*}{ entry } & \multirow{3}{*}{$\begin{array}{c}\mathrm{T} \\
\left({ }^{\circ} \mathrm{C}\right)\end{array}$} & \multirow{2}{*}{\multicolumn{2}{|c|}{$\begin{array}{l}\mathrm{t} \\
\text { (h) }\end{array}$}} & \multicolumn{2}{|c|}{ yield } & \multirow{3}{*}{$\overline{\mathrm{DP}_{\mathrm{n}}^{\text {th }}}$} & \multicolumn{2}{|c|}{$\overline{\mathrm{DP}_{\mathrm{n}}^{\mathrm{GPC}}}$} & \multirow{2}{*}{$\begin{array}{c}\overline{\mathrm{M}_{\mathrm{n}}^{\mathrm{th}}} \\
\left(\mathrm{g} \cdot \mathrm{mol}^{-1}\right)\end{array}$} & \multicolumn{2}{|c|}{$\overline{\mathrm{M}_{\mathrm{n}}^{\mathrm{GPC}}}$} & \multirow{2}{*}{\multicolumn{2}{|c|}{$\mathrm{Ip}$}} \\
\hline & & & & & & & & & & (g.1 & $\left.\mathrm{ol}^{-1}\right)$ & & \\
\hline & & & b & & & & & $\mathrm{b}$ & & $\mathrm{a}$ & $\mathrm{b}$ & $\mathrm{a}$ & $\mathrm{b}$ \\
\hline 1 & 61 & & 96 & 52 & 59 & 10 & 60 & 84 & 970 & 5200 & 7400 & $1.3_{4}$ & $1.5_{7}$ \\
\hline
\end{tabular}




\begin{tabular}{l|c|cc|cc|ccc|cccc|cc}
\hline 2 & 81 & 47 & --- & 89 & 61 & 10 & 48 & 44 & 970 & 4200 & 4000 & $1.4_{9}$ & $1.8_{0}$ \\
3 & 81 & 47 & 150 & 83 & --- & 20 & 76 & 89 & 1800 & 6500 & 7600 & $1.4_{9}$ & $1.3_{4}$ \\
4 & 81 & 47 & --- & 77 & --- & 30 & 95 & --- & 2700 & 8100 & --- & $1.4_{4}$ & --- \\
5 & 81 & 47 & 24 & 55 & 34 & 40 & 98 & 48 & 3500 & 8400 & 4400 & $1.4_{4}$ & $1.6_{0}$ \\
\hline
\end{tabular}

${ }^{\mathrm{a}}$ : our work on GCTs.

${ }^{\mathrm{b}}$ : CROP of MOx using Solk-Ts.[20]

Insert Table 1.

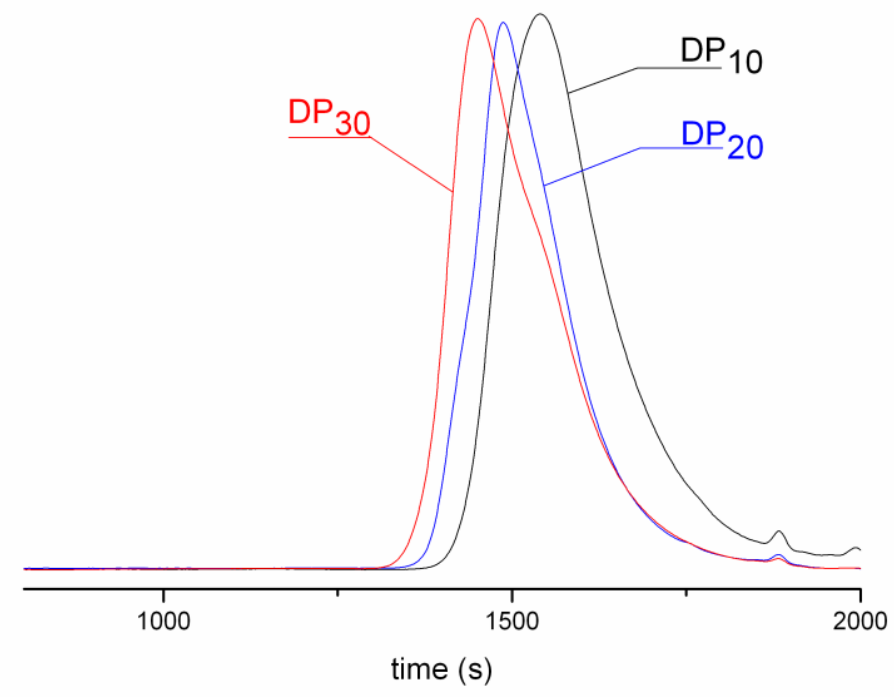

Insert Figure 4.

Simultaneous functionalization of polyoxazoline end chains using isocyanate and carbonate routes 
Polyoxazolines bearing carbonate and oxazolinium end chains were converted to telechelic POx according to two alternative routes as described in Scheme 4. The reactive telechelic polymers GC-POx ${ }^{\text {ium }}$ or $(\mathbf{H O})_{2}$-POx-OH can act as precursor for functional materials. In this way, polyurethanes are usually prepared from diols and water-sensitive diisocyanates (isocyanate route). In our case $(\mathbf{H O})_{2}-\mathbf{P O x}-\mathbf{O H}$ bearing $\alpha$-diol and $\omega$-hydroxyl end groups reacted with a peculiar isocyanate: 3-(triethoxysilyl)propyl isocyanate (TESPI) (isocyanate route in Scheme 4). TESPI provides polymers with the ability to produce organic-inorganic hybrid materials.[26] In the isocyanate route (Ur-POx-Ur) polymer was prepared by urethanization of (HO) $)_{2}$-POx-OH with TESPI (4.25 equiv with respect to the O-H groups) at $35^{\circ} \mathrm{C}$ in presence of $\mathrm{n}-\mathrm{Bu}_{2} \mathrm{Sn}(\mathrm{lau})_{2}$.[27] The reaction of urethanization of hydroxyl group can be monitored by FTIR since the large and intense isocyanate band at $2256 \mathrm{~cm}^{-1}$ disappeared on Ur-POx-Ur spectrum as evidenced in Figure 5. The large peak assignable to $\mathrm{OH}$ bond at $3437 \mathrm{~cm}^{-1}$ also decreased. Moreover the appearance of a peak at $1557 \mathrm{~cm}^{-1}$ proves the formation of urethane groups $(\mathrm{H}-\mathrm{N}-\mathrm{C}=\mathrm{O}$ amide $\mathrm{II})$. We noted that carbonyl urethane stretching peak close to $1629 \mathrm{~cm}^{-1}$ overlapped that of polyoxazoline carbonyl one. 


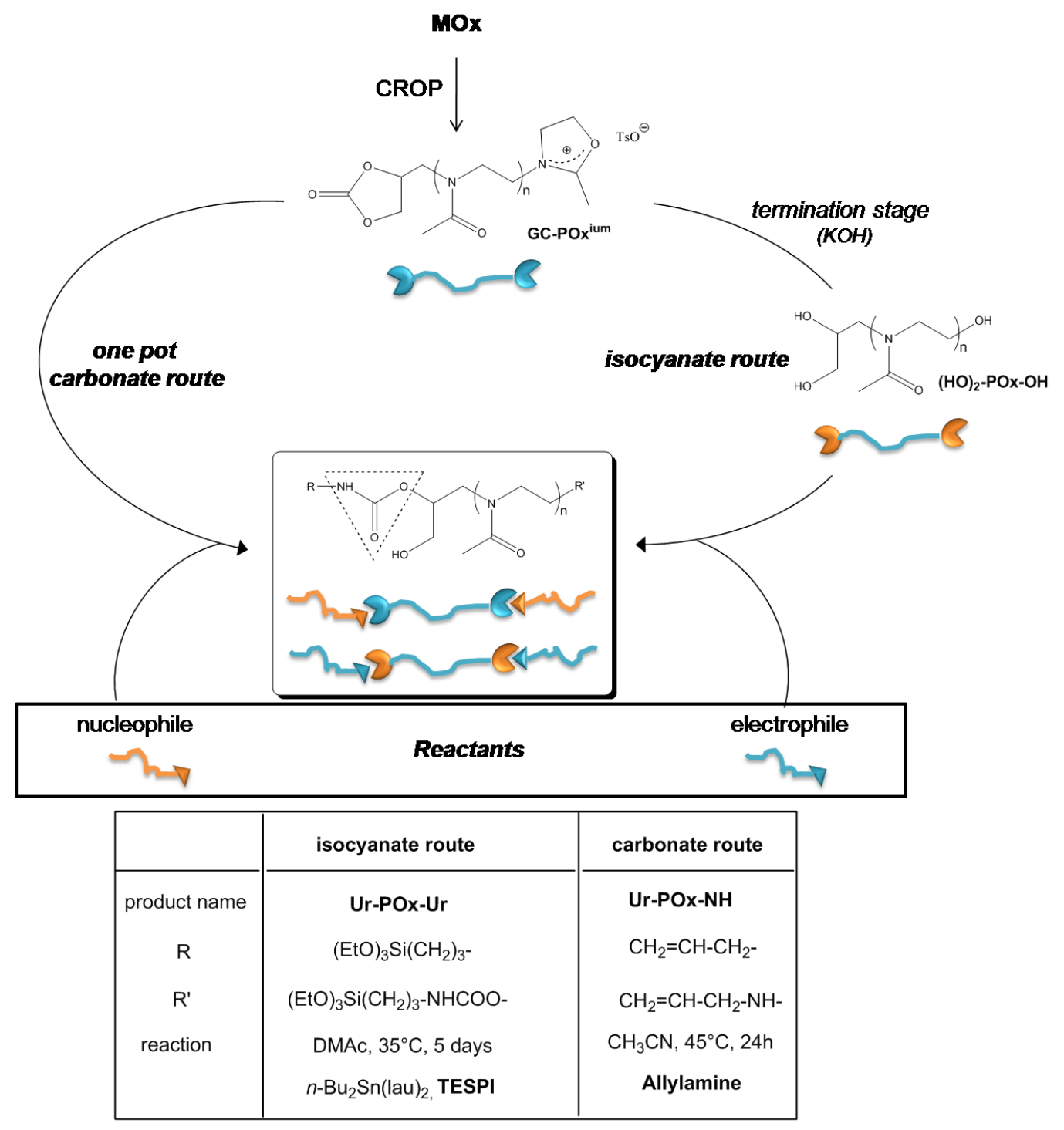

Insert Scheme 4. 


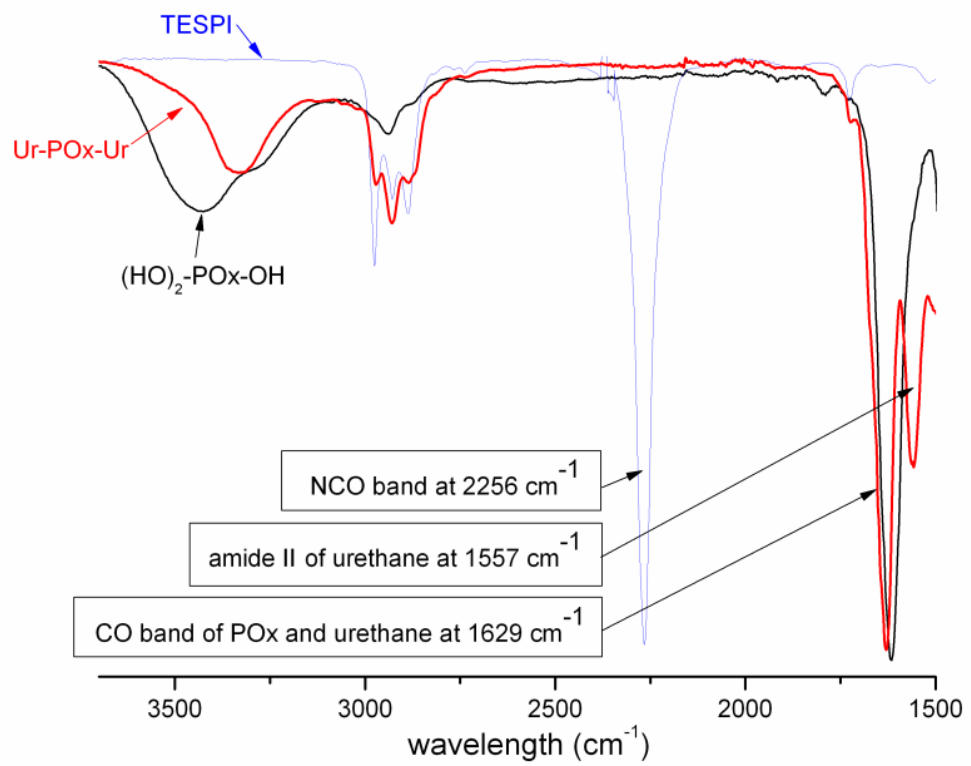

Insert Figure 5.

As an alternative method for preparing urethanes, the chemo-selective reaction of fivemembered cyclic carbonate with amine gives urethanes with hydroxyl groups without employing toxic and unstable isocyanates and without catalyst (carbonate route in Scheme 4). The chemo-selective reaction permits the addition of amines on functional carbonate bearing various groups such as alcohol, amide...[28,29] In our case the urethanization has been attempted using GC-POx ${ }^{\text {ium }}$ and unsaturated amine: allylamine as shown in Scheme 5. Onepot non-isocyanate synthesis of POx bearing urethane group (Ur-POx-NH) was realized during the termination stage of the polymerization without preliminary step. Allylamine acted both as terminating agent in the polymerization of MOx and reactant with the cyclic carbonate $\alpha$-end group. In order to determine the best reaction conditions of the termination stage in the presence of allylamine, the polymerization of MOx was preliminary realized using MeOTs initiator and gave finally (Allyl-POx). The efficiency of the termination agent occurred for $24 \mathrm{~h}$ at $45^{\circ} \mathrm{C}$. Thus at the end of the polymerization of MOx, allylamine was added to the reaction mixture containing GC-POx ${ }^{\text {ium }}$ and the reaction was realized at low 
temperature, $45^{\circ} \mathrm{C}$, in respect to Endo investigations who studied the reactivity of fivemembered cyclic carbonates with amines at low temperature.[30] ${ }^{1} \mathrm{H}$ NMR spectroscopy analysis confirmed the urethanization of carbonate group and the termination of the polymerization with the presence of typical ethylenic signals at 5.9-5.6 and 5.3-4.9 pm coming from allylamine end groups on polyoxazoline (Figure 6). According to the carbonate route, non-isocyanate urethane function beared hydroxyl lateral group (Scheme 5). The obtained urethanes show some useful characteristics such as high water absorption because of the existence of hydroxyl groups that cannot be observed in commercial polyurethanes produced by the addition of diisocyanates with diols. As shown in Scheme 5, the reaction of five-membered cyclic carbonates with amines afforded two adducts (1 and 1'), urethanes with primary or secondary hydroxyl groups. In the case of usual carbonates the ratio of the adducts was determined by ${ }^{1} \mathrm{H}$ NMR integration ratio of the $\mathrm{CH}_{2}$ protons in $\alpha$-position to the hydroxyl group. In our case the $\mathrm{CH}_{2}$ protons of 1 and 1' adducts overlapped in the large peaks at 4.953.7 and the ratio of the adducts could not be quantified as already mentioned in the case of aliphatic dicarbonates.[13] Thanks to Scheme 4 we noted the main differences between the two synthetic routes where in the isocyanate route nucleophilic end groups (hydroxyl and diol groups) were reacted with $(\mathbf{H O})_{2}-\mathbf{P O x}-\mathbf{O H}$ whereas in the carbonate route electrophilic end groups (carbonate and oxazolium groups) were used with GC-POx ${ }^{\text {ium }}$.

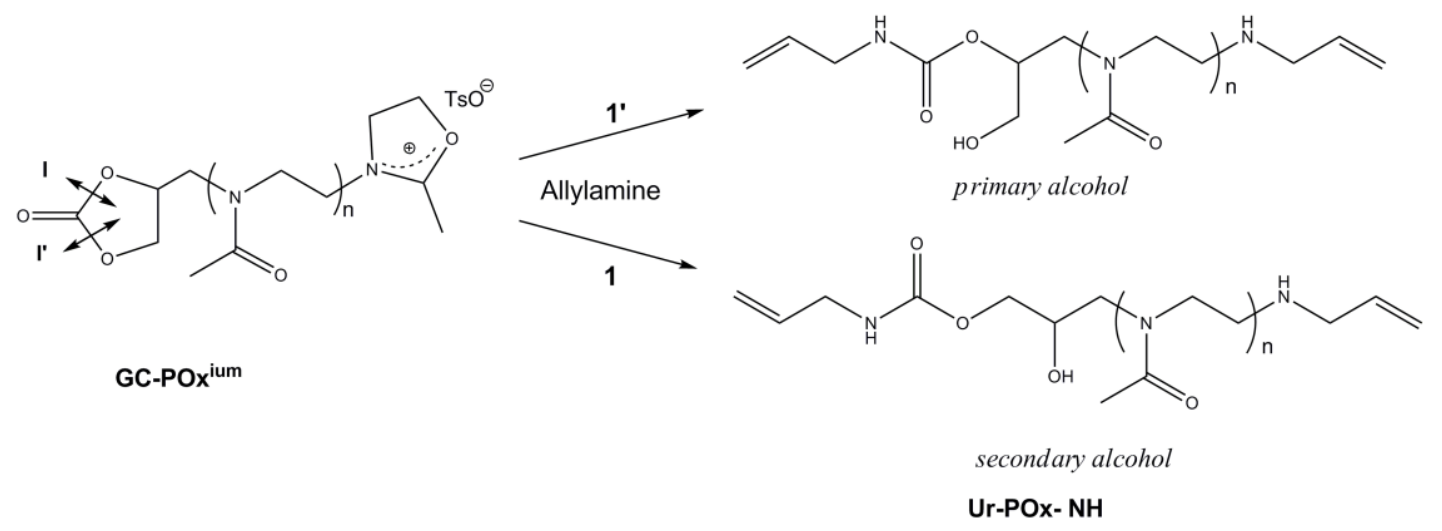

Insert Scheme 5. 


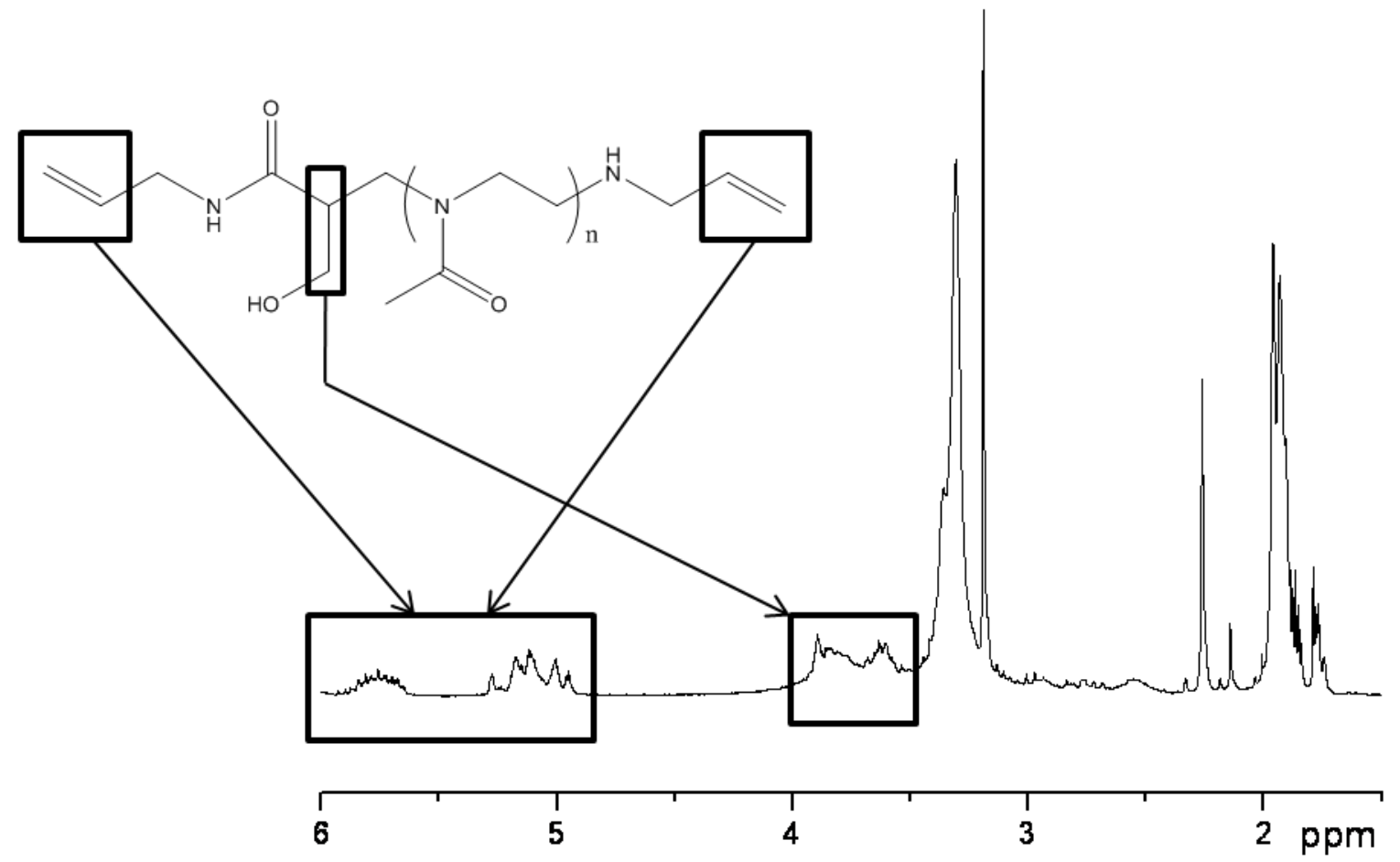

Insert Figure 6. 


\section{Experimental}

\section{Materials}

Pyridine, TsCl, allylamine, MeOTs, 3-(triethoxysilyl)propyl isocyanate (TESPI), di-nbutyltin dilaurate $\left(\mathrm{n}-\mathrm{Bu}_{2} \mathrm{Sn}(\mathrm{lau})_{2}\right)$, DMAc, methanol, diethyl ether, $\mathrm{CuSO}_{4}, \mathrm{KOH}$ and $\mathrm{CaH}_{2}$ were purchased from ACROS and were used as received. 2-Methyl-2-oxazoline (MOx) and MeOTs were dried, distilled from $\mathrm{CaH}_{2}$ and stored under a dry nitrogen atmosphere. Acetonitrile was dried and distilled according to standard procedures.[31] Deuterated solvents $\left(\mathrm{CDCl}_{3}\right.$ and $\left.\mathrm{CD}_{3} \mathrm{CN}\right)$ were purchased from SDS and were used without further purification. Glycerol carbonate (GC) was a generous gift from ONIDOL Corporation.

\section{Analytical techniques}

${ }^{1} \mathrm{H}$ and ${ }^{13} \mathrm{C}$ NMR spectra were recorded using a Bruker $\mathrm{AC} 200$ with $\mathrm{CDCl}_{3}$ or $\mathrm{CD}_{3} \mathrm{CN}$ as solvent. Size exclusion chromatography was performed on a PL-GPC 50 Plus equipped with an RI refractive index detector. Three PL aquagel-OH columns (25, 7.5 and $4.6 \mathrm{~mm} \mathrm{ID)}$ were used at $40^{\circ} \mathrm{C}$ with a $0.8 \mathrm{~mL} \cdot \mathrm{min}^{-1}$ flow rate of $\mathrm{H}_{2} \mathrm{O} / \mathrm{CH}_{3} \mathrm{OH}: 7 / 3\left(0.1 \mathrm{M} \mathrm{LiNO}_{3}\right)$, calibrated using POE standards. Fourier Transform Infrared (FTIR) spectra were recorded with a Perkin Elmer Spectrum 100 spectrometer equipped with an attenuated total reflectance (ATR) crystal. Melting points were measured on a Büchi 530 instrument.

\section{4-(p-toluenesulfonate)methyl-1,3-dioxolan-2-one: GCTs}

GC (10.09 g, $85.52 \mathrm{mmol})$ and tosyl chloride (24.46 g, $128 \mathrm{mmol}, 1.5 \mathrm{eq})$ were dissolved in dry acetonitrile $(1 \mathrm{M})$. Another acetonitrile solution $(1 \mathrm{M})$ containing pyridine $(13.53 \mathrm{~g}, 171$ mmol, 2 eq) was prepared. At $5^{\circ} \mathrm{C}$ the first solution was added dropwise to the second one. 
The mixture was stirred for $6 \mathrm{~h}$ at room temperature. The reaction mixture was filtered and concentrated under pressure. The resulting product GCTs was isolated in 51\% yield.

${ }^{1} \mathrm{H} \mathrm{NMR}\left(\mathrm{CDCl}_{3}\right) \delta(\mathrm{ppm}): 7.8\left(\mathrm{~d}, 2 \mathrm{H}, \mathrm{H}_{\text {aromatic }}\right), 7.4\left(\mathrm{~d}, 2 \mathrm{H}, \mathrm{H}_{\text {aromatic }}\right), 4.9\left(\mathrm{~m}, 1 \mathrm{H}, \mathrm{CH}_{\text {cyclic }}\right)$, $4.5\left(\mathrm{~d}, 1 \mathrm{H}, \mathrm{CH}_{2 \text { cyclic }}\right), 4.4\left(\mathrm{~d}, 1 \mathrm{H}, \mathrm{CH}_{2 \text { cyclic }}\right), 4.2\left(\mathrm{~m}, 2 \mathrm{H}, \mathrm{CH}_{2}-\mathrm{SO}_{3}\right), 2.4\left(\mathrm{~s}, 3 \mathrm{H}, \mathrm{CH}_{3}\right)$.

${ }^{13} \mathrm{C}$ NMR $\left(\mathrm{CDCl}_{3}\right) \delta(\mathrm{ppm}): 154.2(\mathrm{C}=\mathrm{O}$ cyclic$), 145.8\left(\underline{\mathrm{C}}_{\text {aromatic }}-\mathrm{CH}_{3}\right), 131.7\left(\mathrm{C}_{\text {aromatic }}-\mathrm{S}\right)$, 129.9 and $127.5\left(\mathrm{CH}_{\text {aromatic }}\right), 73.4\left(\mathrm{CH}_{2}-\mathrm{SO}_{3}\right), 68.6\left(\mathrm{CH}_{\text {cyclic }}-\mathrm{O}\right), 65.2\left(\mathrm{CH}_{2 \text { cyclic }}\right), 20.4\left(\mathrm{CH}_{3}\right)$. FTIR $\left(\mathrm{cm}^{-1}\right): 2943(\mathrm{CH}), 1796(\mathrm{C}=\mathrm{C}), 1635(\mathrm{C}=\mathrm{O}), 1425,1172$. $\mathrm{m}_{\mathrm{p}}=108^{\circ} \mathrm{C}$

\section{Typical polymerization of MOx using GCTs: $(\mathrm{HO})_{2}-\mathrm{POx}-\mathrm{OH}$}

All reactions were carried out under a dry nitrogen atmosphere. GCTs initiator and MOx were dissolved in dry acetonitrile (4 M). The solution was vigorously stirred at $81^{\circ} \mathrm{C}$ for $47 \mathrm{~h}$. Then, the product was quenched by addition of $\mathrm{KOH}$-saturated methanolic solution (2.1 eq of $\mathrm{KOH})$. The flask was maintained for $24 \mathrm{~h}$ at RT. After cooling, the polymer was isolated by slow precipitation from cold diethyl ether.

${ }^{1} \mathrm{H}$ NMR $\left(\mathrm{CD}_{3} \mathrm{CN}\right) \delta(\mathrm{ppm}): 3.9-3.6\left(\mathrm{~m}, 5 \mathrm{H}, \mathrm{C}_{2}-\mathrm{OH}, \mathrm{C} \underline{\mathrm{H}}-\mathrm{OH}\right.$ and $\mathrm{C}_{2}-\mathrm{OH}_{\omega}$ end group $), 3.6-3.3$ $\left(\mathrm{m},(4 \mathrm{n}+2) \mathrm{H}, \mathrm{CH}_{2}\right.$ of $\mathrm{POx}$ and $\left.\mathrm{CH}_{2}-\mathrm{N}\right), 2.0\left(\mathrm{~s}, 3 \mathrm{nH}, \mathrm{CH}_{3}\right.$ of $\left.\mathrm{POx}\right)$.

${ }^{13} \mathrm{C}$ NMR $\left(\mathrm{CD}_{3} \mathrm{CN}\right) \delta(\mathrm{ppm}): 171.2-170.6(\mathrm{C}=\mathrm{O}$ of $\mathrm{POx}), \mathrm{CH}-\mathrm{OH}$ not observed, $64.9\left(\mathrm{CH}_{2^{-}}\right.$ $\mathrm{OH}), 46.2-42.8\left(\mathrm{CH}_{2}\right.$ of POx and $\left.\mathrm{CH}_{2}-\mathrm{N}\right), 20.9\left(\mathrm{CH}_{3}\right.$ of POx $)$.

FTIR $\left(\mathrm{cm}^{-1}\right): 3437(\mathrm{OH}), 2936(\mathrm{CH}), 1630(\mathrm{C}=\mathrm{O}), 1416,1175$.

\section{Synthesis of Allyl-POx}

The reaction carried out under a dry nitrogen atmosphere. MeOTs and MOx were dissolved in dry acetonitrile $(4 \mathrm{M})$. The solution was vigorously stirred at $81^{\circ} \mathrm{C}$. The reaction product was quenched by addition of an adequate amount of allylamine (10 eq). The flask was maintained 
for $24 \mathrm{~h}$ at $45^{\circ} \mathrm{C}$. After cooling, Allyl-POx was isolated by slow precipitation from cold diethyl ether. Allyl-POx was isolated in 94\% yield.

${ }^{1} \mathrm{H}$ NMR $\left(\mathrm{CDCl}_{3}\right) \delta(\mathrm{ppm}): 5.8(\mathrm{~m}, 1 \mathrm{H}, \mathrm{CH}=), 5.2\left(\mathrm{~m}, 2 \mathrm{H}, \mathrm{CH}_{2}=\right), 3.9-3.3\left(\mathrm{~m}, 4 \mathrm{nH}, \mathrm{CH}_{2}\right.$ of POx), $2.8\left(\mathrm{~m}, 2 \mathrm{H}, \mathrm{CH}_{2}-\mathrm{N}\right), 2.0\left(\mathrm{~s}, 3 \mathrm{nH}, \mathrm{CH}_{3}\right.$ of $\left.\mathrm{POx}\right)$.

${ }^{13} \mathrm{C}$ NMR $\left(\mathrm{CDCl}_{3}\right) \delta(\mathrm{ppm}): 171.2-170.6(\mathrm{C}=\mathrm{O}$ of $\mathrm{POx}), 132.2(\mathrm{CH}=), 118.1-117.1\left(\mathrm{CH}_{2}=\right)$, 51.1-43.2 $\left(\mathrm{CH}_{2}\right.$ of POx and $\left.\mathrm{CH}_{2}-\mathrm{N}\right), 20.9\left(\mathrm{CH}_{3}\right.$ of POx $)$.

\section{Urethanization of $(\mathrm{HO})_{2}-\mathrm{POx}-\mathrm{OH}$ via isocyanate route: $\mathrm{Ur}-\mathrm{POx}-\mathrm{Ur}$}

After the dissolution of (HO) $)_{2}$-POx-OH $(0.5121 \mathrm{~g}, 1.42 \mathrm{mmol})$ in $20 \mathrm{~mL}$ of DMAc, TESPI $(2.2 \mathrm{~mL}, 6.26 \mathrm{eq})$ and $\mathrm{n}-\mathrm{Bu}_{2} \mathrm{Sn}(\mathrm{lau})_{2}(0.01 \mathrm{~mL}, 0.012 \mathrm{eq})$ were added under nitrogen. The reaction was maintained for 5 days at $35^{\circ} \mathrm{C}$. Ur-POx-Ur was isolated by slow precipitation from cold diethyl ether.

${ }^{1} \mathrm{H}$ NMR $\left(\mathrm{CD}_{3} \mathrm{CN}\right) \delta(\mathrm{ppm}): 4.95(\mathrm{~m}, 1 \mathrm{H}, \mathrm{CH}-\mathrm{O}), 3.6-2.9\left(\mathrm{~m},(4 \mathrm{n}+40) \mathrm{H}, \mathrm{CH}_{2}\right.$ of POx, $\mathrm{CH}_{2}-\mathrm{O}$, $\mathrm{CH}_{2}-\mathrm{N}$ and TESPI), 2.2-1.95 (s, 3nH, $\mathrm{CH}_{3}$ of POx), 1.1 (t, 27H, $\mathrm{CH}_{3}$ of EtOSi).

FTIR $\left(\mathrm{cm}^{-1}\right)$ : $3334(\mathrm{NH}), 2928(\mathrm{CH}), 1629(\mathrm{C}=\mathrm{O}$ of POx), 1557 (C=O amide II of urethane).

\section{Urethanization of GC-POx ${ }^{\text {ium }}$ via carbonate route: Ur-POx-NH}

GCTs initiator and MOx were dissolved in dry acetonitrile (4 M). The solution was vigorously stirred at $81^{\circ} \mathrm{C}$. The reaction product GC-POx ${ }^{\text {ium }}$ was quenched by addition of an adequate amount of allylamine (10 eq). The flask was maintained for $24 \mathrm{~h}$ at $45^{\circ} \mathrm{C}$. After cooling, the polymer was isolated by slow precipitation from cold diethyl ether. Ur-POx-NH was isolated in $61 \%$ yield.

${ }^{1} \mathrm{H}$ NMR $\left(\mathrm{CD}_{3} \mathrm{CN}\right) \delta(\mathrm{ppm}):$ 5.9-5.6 (m, 2H, $\left.\mathrm{CH}=\right), 5.3-4.9\left(\mathrm{~m}, 4 \mathrm{H}, \mathrm{CH}_{2}=\right), 3.9-3.5(\mathrm{~m}, 3 \mathrm{H}$, $\underline{\mathrm{C}}_{2}-\mathrm{OH}, \mathrm{C} \underline{\mathrm{H}}-\mathrm{OH}$ and $\left.\mathrm{C} \underline{\mathrm{H}}-\mathrm{OCONH}\right), 3.5-3.2\left(\mathrm{~m},(4 \mathrm{n}+6) \mathrm{H}, \mathrm{CH}_{2}\right.$ of $\mathrm{POx}, \underline{\mathrm{C}}_{2}-\mathrm{CH}=$ and $\underline{\mathrm{C}}_{2}-$ NCOMe), 2.0-1.6 (s, $3 n \mathrm{nH}, \quad \mathrm{CH}_{3} \quad$ of $\left.\quad \mathrm{POx}\right)$. 


\section{Conclusion}

This study showed that GCTs coming from glycerol carbonate could act as functional initiator in the cationic ring-opening polymerization of oxazoline. The synthesis of polyoxazoline GC-POx ${ }^{\text {ium }}$ carrying $\alpha$-carbonate group and $\omega$-oxazolium group was reported. The carbonate head group could be converted into diol with $\mathrm{KOH}$ addition to give $(\mathbf{H O})_{2_{2}-}$ POx-OH. Thus in situ polymerization and functionalization occurred. The comparison of two bio-based initiators coming from glycerol GCTs and Solk-Ts showed that GCTs offered the narrowest polydispersity and a better control of molecular weight even if its partial efficiency in the initiation step was demonstrated. Then the chemical modification of the end chains of polyoxazoline by urethanization was achieved using two alternative routes. In the isocyanate route the urethanization of hydroxyl end groups of $(\mathbf{H O})_{2}-\mathbf{P O x}-\mathbf{O H}$ with functional isocyanate TESPI was checked by FTIR spectroscopy. In the carbonate route the reaction of nucleophiles as amines with carbonate and oxazolium end chains of GC-POx ${ }^{\text {ium }}$ occurred in the same time as evidenced in NMR study. This work demonstrated that the functional initiator GCTs could be used to generate $\alpha, \omega$-functionalized polyoxazolines. This method is versatile and can accept many nucleophiles compatible with carbonate chemistry and many electrophiles compatible with isocyanate chemistry.

\section{Acknowledgments}

The authors are grateful to ONIDOL Corporation for a generous gift of glycerol carbonate. 


\section{References}

[1] Adams N., Schubert U. S. Adv. Drug Delivery Rev. 2007, 59, 1504-1520.

[2] Woodle M. C., Engbers C. M., Zalipsky S. Bioconjugate Chemistry 1994, 6, 493-496.

[3] Kobayashi S. Progress in Polymer Science 1990, 15, 751-760.

[4] Giardi C., Lapinte V., Charnay C., Robin J. J. React. Funct. Polym. 2009, 69, 643-649.

[5] Biermann U., Friedt W., Lang S., Luhs W., Machmuller G., Metzger J. O., Klaas M. R., Schafer H. J., Schneider M. P. Angew. Chem., Int. Ed. Engl. 2000, 39, 2206-2224.

[6] Jenck J. F., Agterberg F., Droescher M. J. Green Chem. 2004, 6, 544-556.

[7] Zheng Y., Chen X., Shen Y. Chem. Rev. 2008, 108, 5253-5277.

[8] Corma A., Iborra S., Velty A. Chem. Rev. 2007, 107, 2400-2502.

[9] Rokicki G., Rakoczy P., Parzuchowski P. G., Sobiecki M. Green Chem. 2005, 7, 529-539.

[10] Parzuchowski P. G., Jaroch M., Tryznowski M., Rokicki G. Macromolecules 2008, 41, 3859-3865.

[11] Wolfson A., Dlugy C., Shotland Y. Environ. Chem. Lett. 2007, 5, 67-71.

[12] Simao A. C., Lynikaite-Pukleviciene B., Rousseau C., Tatibouet A., Cassel S., Sackus A., Rauter A. P., Rollin P. Lett. Org. Chem. 2006, 3, 10, 744-748.

[13] Tomita H., Sanda F., Endo T. J. Polym. Sci. Part A: Polym. Chem. 2001, 39, 3678-3685.

[14] PCT Patent 1075682008.

[15] UK Patent 24321602007.

[16] Fricke N., Keul H., Möller M. Macromol. Chem. Phys. 2009, 210, 242-255.

[17] Rousseau J., Rousseau C., Lynikaité B., Sackus A., De Leon C., Rollin P., Tatibuët A. Tetrahedron, 2009, 65, 8571-8581.

[18] Shaikh A. A. G., Sivaram S. Chem. Rev. 1996, 96, 951-976.

[19] Clements J. H. Ind. Eng. Chem. Res. 2003, 42, 663-674. 
[20] Einzmann M., Binder W. H. J. Polym. Sci. Part A: Polym. Chem. 2001, 39, 2821.

[21] Brissault B., Guis C., Cheradame H. Eur. Polym. J. 2002, 38, 219-228.

[22] Saegusa T., Ikeda H. Macromolecules 1973, 6, 808-811.

[23] Matyjaszewski K., Cationic polymerizations: mechanisms, synthesis, and applications, Marcel Dekker Inc., New York, 1996.

[24] Hoogenboom R., Fijten M. W. M., Schubert U. S. J. Polym. Sci. Part A: Polym. Chem. 2004, 42, 1830-1840.

[25] Hoogenboom R., Paulus R. M., Fijten M. W. M., Schubert U. S. J. Polym. Sci. Part A: Polym. Chem. 2005, 43, 1487-1497.

[26] Sakka S., Handbook of Sol-Gel Science and Technology: Processing, Characterization and Applications, V. I - Sol-Gel Processing, Kluwer Academic Publishers, 2005.

[27] Pardal F., Lapinte V., Robin J.J. J. Polym. Sci. Part A: Polym. Chem. 2009, 47, 46174628.

[28] Ochiai B., Satoh Y., Endo T. Green Chem. 2005, 7, 765-767.

[29] Ochiai B., Inoue S., Endo T. J. Polym. Sci. Part A: Polym. Chem. 2005, 43, 6613-6618.

[30] Tomita H., Sanda F., Endo T. J. Polym. Sc. Part A Polym. Chem. 2001, 39, 4091-4100.

[31] Perrin. D., Purification of laboratory chemicals. New york: Pergamon press, 1980. 


\section{Table captions}

Table 1. Characterization data for CROP of MOx using Solk-Ts and GCTs initiators.

\section{Figure captions}

Figure 1. Study of the initiation stage by ${ }^{1} \mathrm{H}$ NMR analysis in $\mathrm{CDCl}_{3}$ (*: residual $\mathrm{CHCl}_{3}$ ).

Figure 2. Evolution of conversion versus time of polymerization using GCTs at 61 and $81{ }^{\circ} \mathrm{C}$.

Figure 3. $\operatorname{Ln}\left([\mathrm{M}]_{0} /[\mathrm{M}]\right)$ versus reaction time for MOx using GCTs $\left(\diamond 81^{\circ} \mathrm{C}, \star 61^{\circ} \mathrm{C}\right)$.

Figure 4. GPC traces of various lengths of $(\mathbf{H O})_{2}-\mathbf{P O x}-\mathbf{O H}$ chain.

Figure 5. FTIR spectra of TESPI, $(\mathrm{HO})_{2}-\mathrm{POx}-\mathrm{OH}$ and Ur-POx-Ur.

Figure 6. ${ }^{1} \mathrm{H}$ NMR spectrum of Ur-POx-NH in $\mathrm{CDCl}_{3}$. 


\section{Graphical}

The synthesis of polyoxazoline has been achieved via cationic ring-opening polymerization of 2-methyl-2-oxazoline using glycerol carbonate derivative as bio-based initiator. The article focuses on end group modifications using isocyanate and carbonate routes.

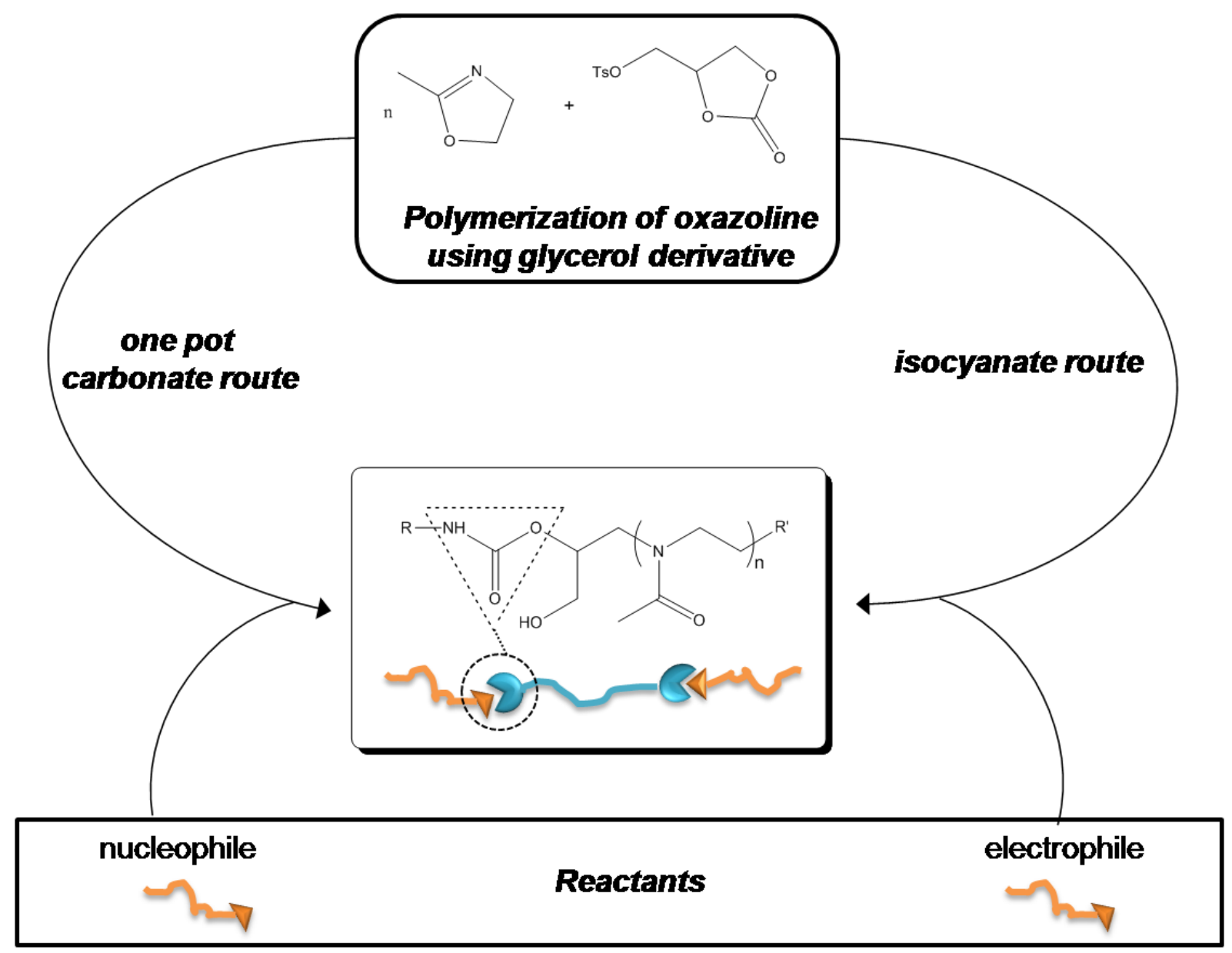

